\title{
ARANOFLAVIN, A NEW ANTIBIOTIC
}

\author{
Kimio Mizuno, Takuji Ando and Jinnosuke Abe \\ Research Laboratory, Toyo Jozo Co., Ltd., \\ Ohito-cho, Tagata-gun, Shizuoka-ken, Japan \\ (Received for publication September 16, 1970)
}

\begin{abstract}
A new antibiotic, named aranoflavin, which inhibits growth of bacteria, protozoa, and tumor cells in vivo, has been isolated from Arachniotus flavoluteus. The antibiotic was separated into related two components designated as aranoflavin $\mathrm{A}\left(\mathrm{C}_{23} \mathrm{H}_{33} \mathrm{NO}_{6}\right)$, and aranoflavin $\mathrm{B}\left(\mathrm{C}_{26} \mathrm{H}_{39} \mathrm{NO}_{9}\right)$.
\end{abstract}

During our screening for new antibiotics from fungi, a new antibiotic, aranoflavin, has been isolated from the culture broth of Arachniotus flavoluteus ${ }^{1,2)}$ NHL 2271. The production, isolation and properties of the antibiotic are presented in this paper.

\section{Production and Isolation}

The organism was cultured at $26^{\circ} \mathrm{C}$ with shaking in a medium containing $2 \%$ glucose, $10 \%$ potato extracts which extracted from $300 \mathrm{~g}$ potato slices in 1 liter of water for 1 hour at $100^{\circ} \mathrm{G}, 0.5 \%$ Pharma media (Traders Oil Mill Co., Ltd.), $0.5 \%$ $\mathrm{KH}_{2} \mathrm{PO}_{4}$ and $0.25 \% \quad \mathrm{MgSO}_{4}$ at $\mathrm{pH} 6.5$.

The antibiotic produced was determined by paper disc method using Staphylococcus aureus FDA $209 \mathrm{P}$ as a test organism. The cultured broth was harvested af ter 72-hour fermentation.

Aranoflavin is a solvent-extractable antibiotic complex, which is obtained mainly from mycelium but also in smaller amounts of it from culture filtrate.

The mycelial cake obtained by filtration of the harvested broth (5 liters, $\mathrm{pH}$ 6.2) was extracted twice with 1 liter of acetone. The extracts were concentrated under reduced pressure and the remaining aqueous solution was extracted with 1 liter of butyl acetate.

The antibiotic in the broth filtrate (4 liters, $60 \mathrm{mcg} / \mathrm{ml}$ ) was extracted twice with 1.5 liters of butyl acetate. Both the extracts from mycelium and filtrate were combined and concentrated in vacuo to an oily syrup. Two active spots were detected at Rf 0.7 and 0.45 with bioautography of thin-layer chromatography (TLC) using silicic acid (Merck, Kieselgel G, solvent system: ethyl acetate).

In order to separate aranoflavin complex, the syrup in $10 \mathrm{ml}$ of ethyl acetate was applied on silicic acid column (Mallinckrodt, 100 mesh) and developed with benzene ethyl acetate $(4: 1)$.

Two main active eluates were colleted and evaporated to dryness. These two fractions were named aranoflavin $\mathrm{A}(2.5 \mathrm{~g})$ and aranoflavin $\mathrm{B}(1.0 \mathrm{~g})$, respectively.

Further purification of each component was carried out by silicic acid column 
chromatography. When the column was developed with benzene-ethyl acetate in the ratio of $2: 1$ and $1: 1,1.0 \mathrm{~g}$ aranoflavin $\mathrm{A}$ and $0.5 \mathrm{~g}$ aranoflavin $\mathrm{B}$ were recovered.

\section{Physico-chemical Properties}

Pure aranoflavins $A$ and $B$ are colorless powders. The antibiotics were obtained in crystalline form from benzene, however, crystallinity was lost upon drying. The physicochemical properties of the antibiotics were summarized in Table 1.

As shown in Table 1 and Fig. 1, the components $A$ and $B$ exhibiting same ultraviolet absorption maxima are suggested to have chemically close relationship with each other. The infrared spectra are shown in Fig. 2. The NMR spectra in $\mathrm{CDCl}_{3}$ measured at 60 $\mathrm{MHz}$ are indicated in Fig. 3.

The antibiotic is relatively stable at neutral and acidic $\mathrm{pH}$ but very labile at alkaline $\mathrm{pH}$.

\section{Biological Properties}

The antibacterial and antiprotozoal activities of aranoflavin determined by agar dilution method are given in Table 2.

The results shown in Table 2 demonstrated that aranoflavin $\mathrm{A}$ is more active than $B$. The antibiotic

Table 1. Physico-chemical properties of aranofavin

\begin{tabular}{|c|c|c|}
\hline & Aranofavin $A$ & Aranoflavin $B$ \\
\hline M. p. & $123 \sim 125^{\circ} \mathrm{C}$ & $93 \sim 95^{\circ} \mathrm{C}$ \\
\hline$[\alpha]_{\mathrm{D}}^{23}$ & $-10^{\circ}\left(c \quad 0.5, \mathrm{CHCl}_{3}\right)$ & inactive \\
\hline $\begin{array}{l}\text { M. w. (Mass } \\
\text { spectrometry) }\end{array}$ & 419 & 477 \\
\hline Anal: Found & C 65.74 & C 64.88 \\
\hline & $\mathrm{H} \quad 7.80$ & $\mathrm{H} \quad 8.43$ \\
\hline & $\begin{array}{l}\text { N } 3.36 \\
\text { no } S \& \text { halogen }\end{array}$ & $\begin{array}{l}\text { N } 2.90 \\
\text { no } S \& \text { halogen }\end{array}$ \\
\hline Calcd. & C 65.85 & C 65.38 \\
\hline & $\mathrm{H} \quad 7.93$ & $\mathrm{H} \quad 8.23$ \\
\hline & $\mathrm{N} \quad 3.34$ & $\mathrm{~N} \quad 2.93$ \\
\hline Formula & $\mathrm{C}_{23} \mathrm{H}_{33} \mathrm{NO}_{6}$ & $\mathrm{C}_{26} \mathrm{H}_{39} \mathrm{NO}_{7}$ \\
\hline $\mathrm{UV} \lambda_{\max }^{\mathrm{MeOH}}$ & $266 \mathrm{~m} \mu\left(\mathrm{E}_{1 \mathrm{~cm}}^{1 \%} 800\right)$ & $266 \mathrm{~m} \mu\left(\mathrm{E}_{1 \mathrm{em}}^{1 \%} 690\right)$ \\
\hline $\begin{array}{l}\text { Solubility } \\
\text { soluble : }\end{array}$ & $\begin{array}{l}\text { lower alcohols } \\
\text { acetone, } \mathrm{CHCl}_{3} \text {, } \\
\text { esters }\end{array}$ & $\begin{array}{l}\text { lower alcohols } \\
\text { acetone, } \mathrm{CHCl}_{3} \text {, } \\
\text { esters }\end{array}$ \\
\hline insoluble : & $\begin{array}{l}\mathrm{H}_{2} \mathrm{O}, \mathrm{CCl}_{4} \text {, } \\
\text { petroleum ether }\end{array}$ & $\begin{array}{l}\mathrm{H}_{2} \mathrm{O}, \mathrm{CCl}_{4} \text {, } \\
\text { petroleum ether }\end{array}$ \\
\hline Color reaction & & \\
\hline positive: & $\begin{array}{l}\text { Tollens, } \\
\text { permanganate }\end{array}$ & $\begin{array}{l}\text { ToLLENS, } \\
\text { permanganate }\end{array}$ \\
\hline negative: & $\begin{array}{l}\mathrm{FeCl}_{3} \text {, ninhydrin, } \\
\text { EHRLCH }\end{array}$ & $\begin{array}{l}\mathrm{FeCl}_{3} \text {, ninhydrin, } \\
\text { EHRLICH }\end{array}$ \\
\hline $\begin{array}{l}\text { TLC : Rf } \\
\text { (Merck, } \\
\text { Kieselgel G, } \\
\text { Ethyl acetate) }\end{array}$ & 0.70 & 0.45 \\
\hline
\end{tabular}

Fig. 1. Ultraviolet spectra of aranoflavin.

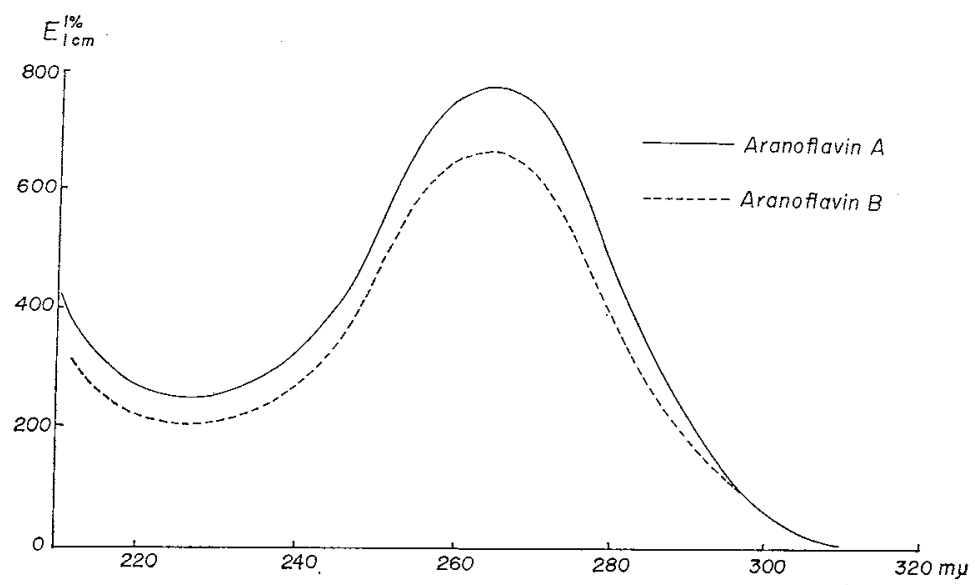


Fig. 2. Infrared spectra of aranofiavin (KBr)

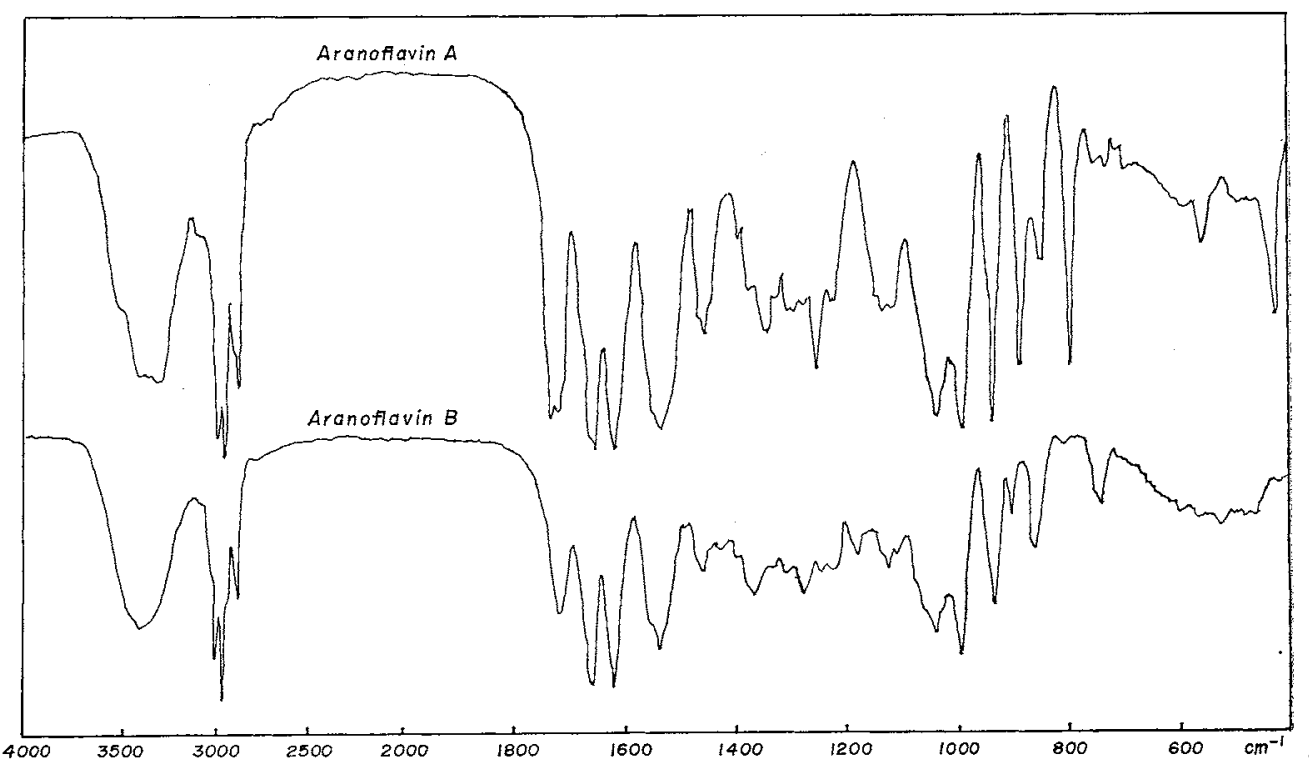

has no antifungal activity.

Aranoflavin A showed cytotoxic

Fig. 3. NMR spectra of aranoflavin $(60 \mathrm{MHz}$

fect at $1.0 \mathrm{mcg} / \mathrm{ml}$, and cytostatic effect at $0.5 \mathrm{mcg} / \mathrm{ml}$ on $\mathrm{HeLa}$ cells, and also showed similar effect on $\mathrm{L}$ cells, CEF cells, and HEL cells in tissue culture.

The antimycoplasma activities were measured by broth dilution method (Table 3).

Moderate prolongation in the survival period of mice inoculated with lymphatic leukemia L-1210 was observed by intraperitoneal administration of aranoflavin A. At daily doses of $5 \mathrm{mcg}$ per mouse for 3 days, prolongation rate of the survival period was $150 \%$.

The antitumor activity of aranoflavin A was also observed on mouse ascites tumor with sarcoma 180 , and the in $\mathrm{CDCl}_{3}$, internal reference : TMS) Aronofiavin A

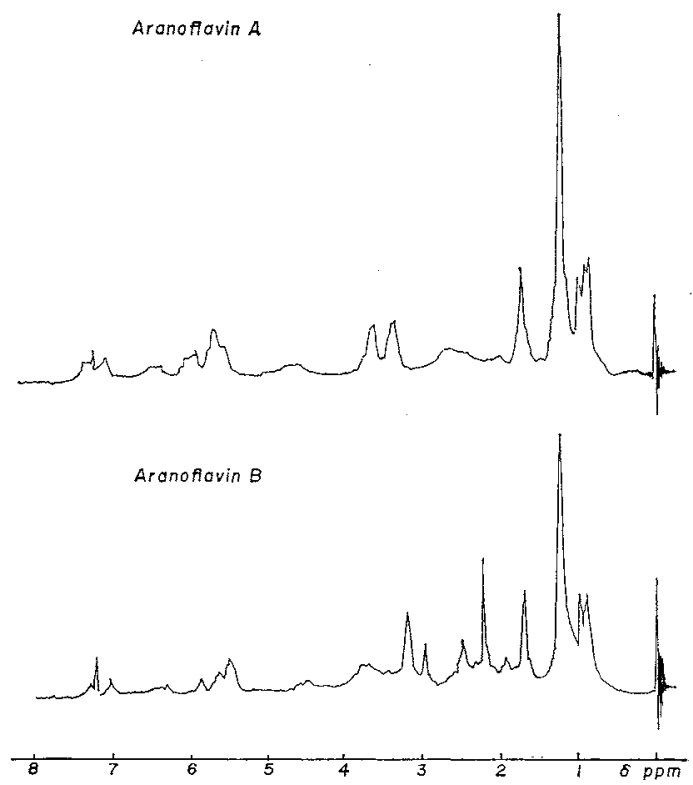
results are given in Table 4 .

The intraperitoneal $\mathrm{LD}_{50}$ of aranoflavin $\mathrm{A}$ in mice was $4.6 \mathrm{mg} / \mathrm{kg}$ body weight, and no toxicity was observed at $100 \mathrm{mg} / \mathrm{kg}$ of aranoflavin $\mathrm{B}$.

\section{Discussion}

Two active components aranoflavins $\mathrm{A}$ and $\mathrm{B}$, were obtained from the cultured broth of Arachniotus flavoluteus. Aranoflavins A and B are thought to be related as suggested 
Table 2. Antimicrobial activites of aranoflavin

\begin{tabular}{c|c|c}
\hline \multirow{2}{*}{ Test organism } & \multicolumn{2}{|c}{$\begin{array}{c}\text { Minimum inhibitory } \\
\text { concentration (mcg/mi) }\end{array}$} \\
\cline { 2 - 3 } Aranoflavin & Aranoflavin \\
Pseudomonas aeruginosa & $>100$ & $>100$ \\
Escherichia coli NIHJ & 25 & $>100$ \\
" B & $>100$ & $>100$ \\
Klebsiella pneumoniae PCI 602 & 12.5 & $>100$ \\
Proteus vulgaris OX 19 & 12.5 & $>100$ \\
Salmonella paratyphi A & 12.5 & $>100$ \\
" B & 12.5 & $>100$ \\
" enteritidis & $>100$ & $>100$ \\
Shigella dysenteriae E-1 & 25 & $>100$ \\
" flexneri & 50 & $>100$ \\
" sonnei E-33 & $>100$ & $>100$ \\
Bacillus subtilis PCI 219 & $<0.2$ & 3.2 \\
Staphylococcus aureus FDA 209P & 0.8 & 25 \\
" albus & 0.8 & 25 \\
" citreus & 0.8 & 25 \\
Micrococcus flavus & 0.8 & 0.8 \\
Sarcina lutea & 0.8 & $<0.2$ \\
Vibrio A A B & 6.3 & $>100$ \\
" B & 1.6 & $>100$ \\
Mycobacterium 607 & $>100$ & 50 \\
Trichomonas vaginalis TV-1099 & $3.13 \sim 1.56$ & 50 \\
\hline
\end{tabular}

Table 4. Antitumor activity of aranoflavin $\mathrm{A}$ on mouse ascites tumor (sarcoma 180)

\begin{tabular}{c|c|c|c}
\hline Dose $(\mathrm{mg} / \mathrm{kg})$ & $\begin{array}{c}\text { No. of } \\
\text { mice }\end{array}$ & Death/Treated & $\begin{array}{c}\text { Ave. of tumor } \\
\text { weight }(\mathrm{g})\end{array}$ \\
\hline 2.0 & 4 & $2 / 4$ & 0.00 \\
1.5 & 4 & $1 / 4$ & 0.00 \\
0.5 & 4 & $0 / 4$ & 0.00 \\
0.25 & 4 & $0 / 4$ & 1.37 \\
Saline (control) & 10 & $0 / 10$ & 5.38 \\
\hline
\end{tabular}

Treatment was started 24 hours after tumor inoculation and made once daily intraperitoneally for 6 days.
Table 3. Antimycoplasma activities of aranoflavin $A$

\begin{tabular}{l|c}
\hline Test organism & $\begin{array}{c}\text { Minimum } \\
\text { inhibitory } \\
\text { concentration } \\
\text { (mcg/ml) }\end{array}$ \\
\hline Mycoplasma pneumoniae & 0.6 \\
M. gallisepticum & 0.6 \\
M. hominis & 5.0 \\
M. laidlowii & 0.05
\end{tabular}

by their ultraviolet and infrared spectra; however, it is very interesting that differences were observed in the biological tests. Aranoflavin $A$ is more active and more toxic than aranoflavin B.

Compared with known antibiotics exhibiting ultraviolet absorption maximum at $266 \mathrm{~m} \mu$, no similar antibiotics were found in literatures except Rhi-12-6483), which was easily differentiated from aranoflavin by the presence of chlorine atom in the molecule and antifungal activity.

Other species of Arachniotus have been reported to produce another antibiotic, aranotin ${ }^{4}$, which can be distinguished from aranoflavin since aranotin has sulphur atoms in the molecule.

\section{Acknowledgements}

The authors wish to express their sincere thanks to Dr. S. UDAGawa, National Institute of Hygienic Science, for kind supply of the strain, Arachniotus flavoluteus NHL 2271, and to Prof. N. Ismida, Tohoku University, for measurement of antitumor activities.

They also indebted to Dr. H. HoRIE, Institute of Microbial Chemistry, for antiprotozoal assay, and Dr. S. OHMura of Kitasato Institute for the measurement of mass spectra.

\section{References}

1) Udagawa, S. : Notes on some Japanese Ascomycetes. I. Transact. Mycol. Soc. Japan $4: 94 \sim$ 102,1963

2) Kuenn, H. H. \& G. F. OrR : Observation on Gymnoascaceae. VI. A new species of arachniotus. Mycologia $51: 864 \sim 870,1959$

3) SAndoz Co., Ltd. : A process for the production of antibiotic. Japanese Patent 8,718, Apr. 4, 1968

4) Neuss, N.; L. D. Boeck, D. R. Brannon, J. S. Cline, D. C. Delong, M. Gorman, L. L. Huckstep, D. H. Lively, J. Mabe, M. M. Marsh, B. B. Molloy, R. Nagarajan, Janet D. Nelson \& W. M. StarK : Aranotin and related metabolites from Arachniotus aureus (EIdam) Schroeter. Antimicr. Agents \& Chemoth.-1968: 213 219, 1969 